\title{
Combined hyperlipidemia is associated with increased exercise-induced muscle protein release which is improved by triglyceride-lowering intervention.
}

Citation for published version (APA):

Smit, J. W., de Bruin, T. W. A., Eekhoff, E. M., Glatz, J. F., \& Erkelens, D. W. (1999). Combined hyperlipidemia is associated with increased exercise-induced muscle protein release which is improved by triglyceride-lowering intervention. Metabolism-Clinical and Experimental, 48(12), 1518-1523. https://doi.org/10.1016/S0026-0495(99)90239-1

Document status and date:

Published: 01/01/1999

DOI:

10.1016/S0026-0495(99)90239-1

Document Version:

Publisher's PDF, also known as Version of record

Document license:

Taverne

Please check the document version of this publication:

- A submitted manuscript is the version of the article upon submission and before peer-review. There can be important differences between the submitted version and the official published version of record.

People interested in the research are advised to contact the author for the final version of the publication, or visit the DOI to the publisher's website.

- The final author version and the galley proof are versions of the publication after peer review.

- The final published version features the final layout of the paper including the volume, issue and page numbers.

Link to publication

\footnotetext{
General rights rights.

- You may freely distribute the URL identifying the publication in the public portal. please follow below link for the End User Agreement:

www.umlib.nl/taverne-license

Take down policy

If you believe that this document breaches copyright please contact us at:

repository@maastrichtuniversity.nl

providing details and we will investigate your claim.
}

Copyright and moral rights for the publications made accessible in the public portal are retained by the authors and/or other copyright owners and it is a condition of accessing publications that users recognise and abide by the legal requirements associated with these

- Users may download and print one copy of any publication from the public portal for the purpose of private study or research.

- You may not further distribute the material or use it for any profit-making activity or commercial gain

If the publication is distributed under the terms of Article $25 \mathrm{fa}$ of the Dutch Copyright Act, indicated by the "Taverne" license above, 


\title{
Combined Hyperlipidemia Is Associated With Increased Exercise-Induced Muscle Protein Release Which Is Improved by Triglyceride-Lowering Intervention
}

\author{
J.W.A. Smit, T.W.A. De Bruin, E.M.W. Eekhoff, J. Glatz, and D.W. Erkelens
}

\begin{abstract}
Although myopathy is considered an adverse effect of treatment with 3-hydroxy-3-methylglutaryl-coenzyme A (HMG-CoA) reductase inhibitors and fibrates in combined hyperlipidemia, the present study was performed to investigate whether combined hyperlipidemia itself is associated with skeletal muscle pathology and whether lipid-lowering intervention has beneficial effects. To investigate whether combined hyperlipidemia is associated with skeletal muscle pathology, 10 male patients and 15 normolipidemic controls underwent a 45-minute standardized bicycle ergometer test at a load of $2 \mathrm{~W} / \mathrm{kg}$ lean body mass (parallel study). One- and 8-hour postexercise increments in the plasma level of the muscle proteins creatine kinase (CK), myoglobin (Mb), and fatty acid-binding protein (FABP) were assessed as parameters for (subclinical) skeletal muscle pathology. The 8-hour postexercise increments in CK and Mb and 1-hour postexercise increment in Mb were significantly higher in patients than in controls, thus indicating increased exercise-induced muscle membrane permeability in combined hyperlipidemia. To investigate the effects of lipid-lowering intervention on skeletal muscle in combined hyperlipidemia, 21 subjects with combined hyperlipidemia were randomized double-blindly to receive 6 weeks of treatment with fluvastatin 40 $\mathrm{mg} / \mathrm{d}$, gemfibrozil $600 \mathrm{mg}$ twice daily, or combination therapy. All subjects underwent an ergometer test before and after treatment. Gemfibrozil treatment alone reduced the CK increments 8 hours postexercise by $47 \%$ and the FABP increments 1 and 8 hours postexercise by $83 \%$ and $101 \%$, respectively (all $P<.05$ ). Combined treatment reduced Mb increments 1 hour postexercise by $54 \%$ and FABP increments 8 hours postexercise by $44 \%$ (all $P<.05$ ). A highly significant correlation existed between therapy-induced changes in plasma triglycerides and changes in postexercise increments of FABP and Mb. In conclusion, combined hyperlipidemia is associated with an increased exercise-induced release of muscle proteins, which is ameliorated by triglyceride-lowering intervention. As FABP is an indicator for ischemia-induced skeletal muscle pathology, a possible explanation is the impaired muscle blood flow during hypertriglyceridemia, which may be reversed by triglyceridelowering intervention. The mechanism and clinical relevance of these findings remain to be investigated.

Copyright 11999 by W.B. Saunders Company
\end{abstract}

$\mathbf{W}^{\mathrm{H}}$ HILE THE RELATIONSHIP between elevated cholesterol levels and cardiovascular disease is beyond dispute, ${ }^{1}$ controversy exists about the role of elevated triglyceriderich lipoproteins in atherosclerosis. Recent studies have indicated a role of hypertriglyceridemia as a risk factor or risk indicator of cardiovascular disease. ${ }^{2-4}$ As a consequence, triglyceridecarrying lipoproteins should be taken into account when considering lipid-lowering therapy in combined hyperlipidemia. The treatment modalities in combined hyperlipidemia are nicotinic acid, inhibitors of 3-hydroxy-3-methylglutarylcoenzyme A (HMG-CoA) reductase, ${ }^{5}$ and fibric acid derivatives, which decrease serum triglyceride levels by decreasing the synthesis of very-low-density lipoprotein cholesterol and increasing lipoprotein lipase activity. ${ }^{6}$ Combination therapy with HMG-CoA reductase inhibitors plus fibrates is effective in the treatment of combined hyperlipidemia, which has been supported by several studies. ${ }^{7-9}$ However, concern has arisen about myopathy and rhabdomyolysis during therapy with HMG-CoA reductase inhibitors combined with gemfibrozil. ${ }^{10-15}$ Moreover, gemfibrozil itself has also been associated with

From the Department of Internal Medicine, University Hospital, Utrecht, Utrecht; Department of Endocrinology and Metabolic Diseases, Leiden University Medical Center, Leiden; and Departments of Endocrinology and Physiology, Maastricht University, Maastricht, The Netherlands.

Submitted December 9, 1998; accepted June 14, 1999.

Supported in part by a Pioneer Grant from the Dutch Foundation for Scientific Research (T.W.A.D.B.).

Address reprint requests to J.W.A. Smit, MD, PhD, Department of Endocrinology and Metabolic Diseases, $C-4 R$, Leiden University Medical Center, PO Box 9600,2300 RC Leiden, The Netherlands.

Copyright 1999 by W.B. Saunders Company

0026-0495/99/4812-0012\$10.00/0 myopathy. ${ }^{16}$ Although a relationship with these medications seems apparent, elevated plasma muscle protein levels both at rest and after exercise have been observed in untreated familial hypercholesterolemia, as well, ${ }^{17,18}$ leading to the conclusion that elevations of creatine kinase (CK) during therapy with HMGCoA reductase inhibitors may not be caused by these agents alone. It has not been investigated whether combined hyperlipidemia is also associated with increased serum levels of muscle proteins. This may be of importance, because elevated CK levels, which may be observed during therapy for combined hyperlipidemia, are usually attributed to this therapy and not to the disease. Moreover, it can be hypothesized that if combined hyperlipidemia is indeed associated with pathological serum muscle protein levels, lipid-lowering intervention may have beneficial effects.

One of the explanations offered for the elevated muscle protein levels in familial hypercholesterolemia is impaired peripheral muscle blood flow, leading to diminished muscle blood flow. Indeed, it has been demonstrated that apart from coronary blood flow, ${ }^{19-21}$ peripheral blood flow is also impaired in hypercholesterolemia, which can be reversed by lipidlowering therapy. ${ }^{22-24}$ In hypertriglyceridemia, peripheral vascular function is impaired as well, which also can be restored by lipid-lowering intervention. ${ }^{25-27}$

The exercise-induced release of the muscle proteins $\mathrm{CK}$, myoglobin (Mb), and heart-type fatty acid-binding protein $(\mathrm{FABP})^{28-32}$ is a well-established parameter for (sub)clinical muscular pathology. To assess whether combined hyperlipidemia is associated with skeletal muscle pathology, the exerciseinduced release of muscle proteins was compared in subjects with combined hyperlipidemia versus normolipidemic controls. To investigate whether therapy for combined hyperlipidemia has beneficial effects on skeletal muscle, a double-blind, 
randomized, placebo-controlled intervention study was performed. In this study, the release of muscle proteins $\mathrm{CK}, \mathrm{Mb}$, and FABP after standardized exercise was assessed before and after 6 weeks of treatment with fluvastatin and gemfibrozil, both as monotherapy and combined.

\section{SUBJECTS AND METHODS}

\section{Intervention Study}

Informed consent was obtained from all patients. The study protocol was approved by the Medical Ethics Committee of the University Hospital Utrecht. In the intervention study, 21 patients with primary combined hyperlipidemia ( 10 men and 11 women aged $54 \pm 2$ years, mean $\pm \mathrm{SE}$; body mass index [BMI], $26.6 \pm 0.5 \mathrm{~kg} / \mathrm{m}^{2}$ ) were selected among recently diagnosed hyperlipidemic patients from the Lipid Clinic of the University Hospital Utrecht. Patients with diabetes mellitus, renal, hepatic, muscle, or cardiac disease, or therapy with other medications known to be accompanied by myopathy or elevated muscle protein levels were excluded. Secondary causes for combined hyperlipidemia were also excluded. Habitual physical exercise was scored as described previously ${ }^{18}$ using the following scale: 0 , no exercise; 1 , once per month but less than once per week; 2 , at least once per week but of mild or moderate intensity (eg, sports for recreational purposes only); and 3, at least once per week but of high intensity (eg, sports competition or occupation involving heavy and frequent physical activity). The patients entered a dietary baseline period of 8 weeks. A standard lipid-lowering diet was prescribed by a dietician, containing $50 \%$ of calories from carbohydrate, $20 \%$ from protein, and $30 \%$ from fat, with a polyunsaturated to saturated lipid ratio of 1 . Daily intake of cholesterol was less than $300 \mathrm{mg}$. At the end of the 8-week baseline period, patients with low-density lipoprotein (LDL) cholesterol of at least $4.14 \mathrm{mmol} / \mathrm{L}$ and fasting triglycerides of at least $2.3 \mathrm{mmol} / \mathrm{L}$ were randomized in a double-blind manner to be treated for 6 weeks with either fluvastatin $40 \mathrm{mg} / \mathrm{d}$ taken at bedtime and gemfibrozil placebo (fluvastatin group, $n=7$ ), gemfibrozil $600 \mathrm{mg}$ twice daily and fluvastatin placebo (gemfibrozil group, $\mathrm{n}=7$ ), or a combination of fluvastatin $40 \mathrm{mg} / \mathrm{d}$ and gemfibrozil $600 \mathrm{mg}$ twice daily (combined treatment group, $\mathrm{n}=7$ ). The placebo tablets contained lactose and resembled the fluvastatin or gemfibrozil tablets. In the last week of the dietary baseline period and after 6 weeks of active treatment, an exercise provocation test was performed.

\section{Comparison of Subjects With Combined Hyperlipidemia Versus Normolipidemic Controls}

To investigate whether combined hyperlipidemia is associated with a pathological exercise-induced release of muscle proteins, the results from a subgroup of 10 male patients with primary combined hyperlipidemia from the intervention study (age, $43 \pm 2$ years; BMI, $26.1 \pm 0.6$ $\mathrm{kg} / \mathrm{m}^{2}$ ) were compared with those of an age-, BMI-, and habitual exercise-matched normolipidemic control group consisting of 15 healthy males (age, $48 \pm 2$; BMI, $25.8 \pm 0.8$ ) recruited from laboratory personnel and used previously to assess whether primary hypercholesterolemia is associated with increased exercise-induced release of muscle proteins. ${ }^{22}$ Controls were screened for conditions known to influence muscle protein release. Since they were normolipidemic, subjects in the control group were not prescribed a diet.

\section{Ergometer Test}

The bicycle ergometer test was used previously to detect subjects with muscular disease and to study exercise-induced skeletal muscle protein release in hypercholesterolemia, and is described in detail elsewhere. ${ }^{22}$ In short, a 45-minute bicycle ergometer test was performed with a load of $2 \mathrm{~W} / \mathrm{kg}$ lean body mass. The actual workload was registered every 5 minutes. In the intervention study, the workload during the second exercise test (in the last week of the active treatment period) was kept identical to the workload during the first test at any time point for each individual. Female participants performed the second exercise test in the same phase of the menstrual cycle as the first test. The patients were told to avoid strenuous exercise for 48 hours before both tests. Blood samples for $\mathrm{CK}, \mathrm{Mb}$, and $\mathrm{FABP}$ analysis were taken before the exercise test and 1 and 8 hours after the test. It was demonstrated that peak CK levels occur 8 hours after this test. ${ }^{18,28}$

Peak $\mathrm{Mb}$ levels are observed 1 hour after exercise and the same is expected for FABP, as FABP and Mb plasma levels are usually strongly correlated. ${ }^{30-32}$ Exercise-induced muscle damage is reflected by an increment in muscle protein levels after exercise. In the normolipidemic control group, only $\mathrm{CK}$ and $\mathrm{Mb}$ levels were assessed, and therefore, no comparison with the hyperlipidemic patients for exercise-induced FABP levels could be performed.

\section{Laboratory Methods}

Total cholesterol, triglycerides, and CK were determined by enzymatic-colorimetric methods (CHOD-PAP and GPO-PAP; Boehringer, Mannheim, Germany). High-density lipoprotein (HDL) cholesterol was determined in the supernatant after precipitation of apolipoprotein B-containing lipoproteins. LDL cholesterol was calculated using the Friedewald formula, since fasting triglycerides were less than 5.6 $\mathrm{mmol} / \mathrm{L}$ in all subjects on all occasions. ${ }^{33} \mathrm{Mb}$ was determined using the Behring Latex Myoglobin Kit (Behring Diagnostics, Frankfurt, Germany). Heart-type FABP was determined in plasma using an enzymelinked immunosorbent assay of the antigen-capture type (sandwich ELISA). This method has been described in detail elsewhere. ${ }^{30}$ Samples from each subject were measured in duplicate in the same assay, using the average of both values.

\section{Safety Parameters}

The laboratory safety parameters were plasma creatinine, sodium, potassium, bilirubin, alanine aminotransferase, aspartate aminotransferase, and gamma-glutamyl transferase, a hematological profile, and a urinary analysis. A physical examination and measurement of the blood pressure and pulse were performed at each visit during the intervention study. A 12-lead electrocardiogram was performed at the beginning of the baseline period.

\section{Statistical Methods}

All values are presented as the mean $\pm S E$. In the intervention study, lipid parameters and preexercise $\mathrm{CK}, \mathrm{Mb}$, and FABP levels before and after treatment within each group were analyzed with a two-sided, paired Student's $T$ test. The exercise-induced elevations of $\mathrm{CK}, \mathrm{Mb}$, and FABP were analyzed within each group using a paired Wilcoxon test. Data from patients and normolipidemic controls were compared using an unpaired $T$ test for age, BMI, lipids, and baseline CK and $\mathrm{Mb}$. Exercise-induced levels of muscle proteins between the two groups were compared with an unpaired Wilcoxon test. Correlations between lipid levels and exercise-induced muscle protein increments were calculated with linear regression. A $P$ value less than .05 was considered statistically significant.

\section{RESULTS}

\section{Comparison of Subjects With Combined Hyperlipidemia and Normolipidemic Controls}

Patients. In the parallel study, both groups were identical with regard to age, BMI, and habitual exercise (Table 1).

Ergometer test. The exercise-induced CK increase after 1 hour was the same, but at 8 hours after exercise, it was significantly higher in patients with combined hyperlipidemia 
Table 1. Comparison of Subjects With Combined Hyperlipidemia and Normolipidemic Controls

\begin{tabular}{lcc}
\hline \multicolumn{1}{c}{ Characteristic } & Patients & Controls \\
\hline No. of subjects & 10 & 15 \\
Age $(\mathrm{yr})$ & $43.3 \pm 2.2$ & $48 \pm 1.7$ \\
BMl $\left(\mathrm{kg} / \mathrm{m}^{2}\right)$ & $26.1 \pm 0.6$ & $25.8 \pm 0.8$ \\
Exercise score & $1.7 \pm 0.2$ & $1.4 \pm 0.6$ \\
LDL cholesterol (mmol/L) & $5.7 \pm 0.5$ & $3.7 \pm 0.3$ \\
HDL cholesterol (mmol/L) & $0.9 \pm 0.05$ & $1.1 \pm 0.1$ \\
Triglycerides (mmol/L) & $4.2 \pm 0.5$ & $1.2 \pm 0.1$ \\
\hline
\end{tabular}

NOTE. Values are the mean \pm SD.

than in normocholesterolemic controls $(39.1 \pm 6.9 v 9.7 \pm 3.3$ $\mathrm{U} / \mathrm{L}, P=.0002$; Fig 1 ). The increase in $\mathrm{Mb}$ differed significantly between patients and controls both 1 hour after exercise $(17.7 \pm 4.2 \mathrm{ng} / \mathrm{L}$ for patients $v 4.1 \pm 2.8 \mathrm{ng} / \mathrm{L}$ for controls, $P=.006)$ and 8 hours after exercise $(9.2 \pm 2.4 v-5.9 \pm 2.2$ $\mathrm{ng} / \mathrm{L}, P=.0003$ ).

\section{Intervention Study}

Patients. Characteristics of the three treatment groups are listed in Table 2. No clinical adverse effects occurred during the study period or thereafter. One patient from the gemfibrozil group left the study because he found the procedures too burdensome. This patient was not included in any analysis.

Lipid parameters. Plasma lipid concentrations are presented in Table 3. The combined treatment group showed the highest reductions in LDL cholesterol and triglycerides, which were significantly decreased by $29 \%$ and $49 \%$, respectively.

Ergometer test. Each subject had an identical workload at any time point during both exercise tests. Preexercise plasma $\mathrm{CK}, \mathrm{Mb}$, and FABP and exercise-induced increments are shown in Table 4. Preexercise plasma muscle protein levels did not differ between the baseline exercise test and the second exercise test in all three treatment groups. The plasma ratio $\mathrm{Mb} / \mathrm{FABP}$ was more than 10 in all groups before and after both exercise tests (data not shown), which is in line with skeletal muscle as a source of these proteins. ${ }^{30-32}$ After gemfibrozil treatment, postexercise increments of CK ( 8 hours postexercise) and FABP (1 and 8 hours postexercise) were significantly lower versus before therapy. In addition, after combination therapy, the 1-hour postexercise increment of $\mathrm{Mb}$ and the 8-hour postexercise increment of FABP were significantly lower versus before treatment.
Table 2. Patient Characteristics in the Intervention Study (mean \pm SD)

\begin{tabular}{lccc}
\hline \multicolumn{1}{c}{ Characteristic } & Fluvastatin & Gemfibrozil & Combination \\
\hline Sex ratio (male/female) & $3 / 4$ & $3 / 3$ & $3 / 4$ \\
Age $(\mathrm{yr})$ & $56 \pm 8$ & $50 \pm 4$ & $56 \pm 2$ \\
Weight $(\mathrm{kg})$ & $77.6 \pm 2.9$ & $78.4 \pm 4.9$ & $80.3 \pm 2.6$ \\
BMI $\left(\mathrm{kg} / \mathrm{m}^{2}\right)$ & $27.3 \pm 0.7$ & $25.4 \pm 0.4$ & $26.9 \pm 0.5$ \\
\hline
\end{tabular}

Correlation between lipid parameters and muscle proteins. No correlation was found between absolute plasma lipid levels (before or after treatment) and exercise-induced increments of muscle proteins. However, in the intervention study, significant correlations existed between therapy-induced changes in plasma triglyceride levels and changes in $\mathrm{Mb}$ increments ( 1 hour after exercise, $r=.54, P=.016 ; 8$ hours after exercise, $r=.68$, $P=.001)$ and FABP increments 1 hour after exercise $(r=.62$, $P=.016 ;$ Fig 1 ). A striking finding was that in 19 of 20 subjects who completed the intervention study, the direction (increase or decrease) of the therapy-induced change in triglycerides paralleled the direction of change in the 1-hour postexercise FABP increment (Fig 2). No correlations were observed between therapy-induced changes in total cholesterol, LDL cholesterol, or HDL cholesterol and changes in exercise-induced increments in muscle proteins.

\section{DISCUSSION}

The present study was performed to assess whether combined hyperlipidemia is associated with increased exercise-induced release of muscle proteins and whether lipid-lowering intervention has beneficial effects.

We found an indication for increased exercise-induced release of muscle proteins in subjects with combined hyperlipidemia compared with normolipidemic controls. Although the comparison of results between patients and controls should be performed carefully since it cannot be excluded that unknown selection factors may have played a role, special care was taken to exclude the influence of conditions that are known to affect exercise-induced muscle protein release. In the intervention study in both the gemfibrozil treatment group and the combination therapy group, the exercise-induced increments of muscle proteins were smaller as compared with pretreatment values. Although, theoretically, the decreased increments may result from decreased release or increased clearance of muscle

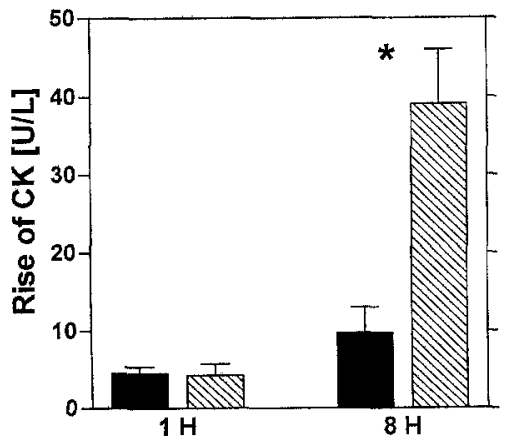

Hours After Exercise

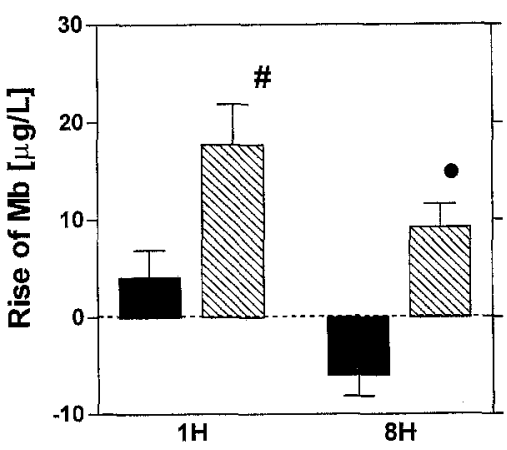

Hours After Exercise
Fig 1. Exercise-induced increments in plasma $\mathrm{CK}$ and $\mathrm{Mb}$ after standardized exercise in $\mathbf{1 0}$ male subjects with combined hyperlipidemia (एa) and 15 normolipidemic male controls (a). Increases in CK 8 hours after exercise and $\mathrm{Mb} 1$ and 8 hours after exercise differed significantly between patients and controls. ${ }^{*} P=.0002, \# P=.006, \cdot P=$ .0003 . 
Table 3. Lipid Profile ( $\mathrm{mmol} / \mathrm{L})$ in 20 Subjects With Combined Hyperlipidemia Before and After 6 Weeks of Treatment With Fluvastatin $40 \mathrm{mg} / \mathrm{d}$, Gemfibrozil $600 \mathrm{mg}$ Twice Daily, or a Combination of Both (Intervention Study)

\begin{tabular}{|c|c|c|c|c|c|c|}
\hline Parameter & $\begin{array}{l}\text { Fluvastatin } \\
(n=7)\end{array}$ & $\Delta \%$ & $\begin{array}{c}\text { Gemfibrozil } \\
\quad(n=6)\end{array}$ & $\Delta \%$ & $\begin{array}{l}\text { Combination } \\
\qquad(\mathrm{n}=7)\end{array}$ & $\Delta \%$ \\
\hline \multicolumn{7}{|l|}{ Baseline } \\
\hline Cholesterol & $8.4 \pm 0.4$ & & $9.0 \pm 0.8$ & & $8.3 \pm 0.4$ & \\
\hline LDLC & $5.4 \pm 0.4$ & & $6.3 \pm 0.7$ & & $5.5 \pm 0.4$ & \\
\hline HDLC & $1.1 \pm 0.1$ & & $1.1 \pm 0.1$ & & $1.2 \pm 0.1$ & \\
\hline TG & $4.3 \pm 0.7$ & & $3.9 \pm 0.4$ & & $3.5 \pm 0.7$ & \\
\hline \multicolumn{7}{|l|}{ After treatment } \\
\hline Cholesterol & $6.5 \pm 0.4^{*}$ & -23 & $7.8 \pm 0.5$ & -13 & $6.0 \pm 0.5 \S$ & -28 \\
\hline LDLC & $3.4 \pm 0.3 \dagger$ & -37 & $5.4 \pm 0.5$ & -14 & $3.9 \pm 0.9$ & -29 \\
\hline HDLC & $1.1 \pm 0.1$ & 0 & $1.3 \pm 0.5$ & +18 & $1.3 \pm 0.1$ & +8 \\
\hline TG & $4.4 \pm 1.1$ & +2 & $2.4 \pm 0.3 \neq$ & -38 & $1.8 \pm 0.3 \pi$ & -49 \\
\hline
\end{tabular}

Abbreviations: LDLC, LDL cholesterol; HDLC, HDL cholesterol; TG, triglycerides.

${ }^{*} P=.009,+P=.003, \ddagger P=.006, \S P=.034, \| P=.012, \pi P=.036: v$ corresponding baseline value.

proteins, the latter seems unlikely since it is known from the literature that neither lipid-lowering drugs as applied in this study nor hyperlipidemia itself affect kidney function in otherwise healthy patients. In addition, creatinine levels in the patient groups remained unchanged throughout the study. In one study, ${ }^{17}$ hypercholesterolemia was associated with increased serum CK-MM and not CK-MBs, which makes an effect of hyperlipidemia on CK clearance unlikely. The decrease in the postexercise FABP increment during gemfibrozil was remarkable, since this agent is known to induce peroxisomes and hence to increase intracellular FABP levels. ${ }^{34}$ If gemfibrozil therapy influenced plasma FABP levels directly, elevated rather than reduced FABP increments would be expected. Analysis of the therapy-induced changes in plasma lipid levels and postexercise muscle protein increments showed a highly significant correlation between improved plasma triglycerides and postexercise $\mathrm{Mb}$ and FABP increments. The correlation between these parameters was even stronger when the direction of the change (positive or negative) was considered: in all but one subject, the direction of the change in triglycerides paralleled the direction of change in the 1-hour postexercise FABP increment. In contrast, no correlation was found between changes in total or LDL cholesterol and changes in muscle proteins. This is in line with the observation that in the groups with the greatest reduction in triglycerides, ie, the gemfibrozil and combined treatment groups, favorable effects on postexercise increments of muscle proteins were found.

These results suggest that combined hyperlipidemia is associated with increased exercise-induced release of muscle proteins and that reducing triglyceride levels has a beneficial effect. As an explanation, it may be suggested that changes in triglyceridecarrying lipoproteins affect muscle membrane stability directly, explaining the reduced leakage of muscle proteins after exercise. This seems unlikely, because cholesterol and phospholipid composition determine cellular membrane stability, rather than plasma triglyceride and fatty acid concentrations. Moreover, the literature suggests a decrease in membrane stability associated with decreased lipid levels. ${ }^{35}$ A direct beneficial effect of the pharmaceutical compounds on muscle is even more unlikely, as both HMG-CoA reductase inhibitors and fibrates have been associated with myopathy. ${ }^{10-15}$ As another explanation, it may be hypothesized that triglyceride-lowering intervention may affect the metabolism of carbohydrates or fatty acids in skeletal muscle, thereby influencing the exercise endurance. However, no such effects were found in a study with gemfibrozil in humans ${ }^{36}$ or a study with peroxisomal proliferators in rats. ${ }^{37} \mathrm{~A}$ more suitable explanation for the observed reduction in the exercise-induced increment of muscle proteins is an improvement in muscle blood flow and, consequently, blood supply to skeletal muscle during triglyceride-lowering therapy. Improved peripheral vascular function has been demonstrated in hypertriglyceridemic subjects treated with fibrates. ${ }^{25}$ Although we did not measure muscle blood flow directly, it has been demonstrated that plasma FABP is a sensitive parameter for ischemiainduced muscular damage. ${ }^{30-32}$ Therefore, we believe improved muscle blood flow is a possible explanation for the beneficial effects on $\mathrm{FABP}$ and $\mathrm{Mb}$ release observed during triglyceride reduction. However, the exact mechanism of the relation between triglyceride and exercise-induced muscle protein lev-

Table 4. Influence of Standardized Exercise on Plasma Levels of CK, $\mathrm{Mb}$, and FABP in 20 Subjects With Combined Hyperlipidemia Before and After 6 Weeks of Treatment With Fluvastatin $40 \mathrm{mg} / \mathrm{d}$, Gemfibrozil $600 \mathrm{mg}$ Twice Daily, or a Combination of Both (Intervention Study)

\begin{tabular}{|c|c|c|c|}
\hline Parameter & $\begin{array}{l}\text { Fluvastatin } \\
\langle\mathrm{n}=7\rangle\end{array}$ & $\begin{array}{l}\text { Gemfibrozil } \\
\qquad\{n=6\}\end{array}$ & $\begin{array}{l}\text { Combination } \\
\qquad(n=7)\end{array}$ \\
\hline \multicolumn{4}{|l|}{ CK $(\mathrm{U} / \mathrm{L})$} \\
\hline \multicolumn{4}{|c|}{ First exercise test } \\
\hline Preexercise & $71.9 \pm 7.6$ & $74.5 \pm 7.1$ & $52.9 \pm 4.3$ \\
\hline$\Delta t=1 \mathrm{~h}$ & $4.0 \pm 2.2$ & $2.7 \pm 1.0$ & $2.9 \pm 1.5$ \\
\hline$\Delta t=8 h$ & $41.0 \pm 12.0$ & $43.3 \pm 13.8$ & $31.9 \pm 8.2$ \\
\hline \multicolumn{4}{|c|}{$\begin{array}{l}\text { Second exercise } \\
\text { test }\end{array}$} \\
\hline Preexercise & $71.6 \pm 7.3$ & $73.3 \pm 11.0$ & $45.1 \pm 14.6$ \\
\hline$\Delta t=1 h$ & $5.1 \pm 1.9$ & $3.5 \pm 3.0$ & $8.0 \pm 2.5$ \\
\hline$\Delta t=8 h$ & $46.3 \pm 19.6$ & $23.0 \pm 6.9^{*}$ & $52.9 \pm 24.8$ \\
\hline \multicolumn{4}{|l|}{$\mathrm{Mb}(\mu \mathrm{g} / \mathrm{L})$} \\
\hline \multicolumn{4}{|c|}{ First exercise test } \\
\hline Preexercise & $30.1 \pm 4.1$ & $30.5 \pm 3.3$ & $23.2 \pm 3.0$ \\
\hline$\Delta t=1 h$ & $17.0 \pm 5.9$ & $15.5 \pm 4.7$ & $12.3 \pm 9.2$ \\
\hline$\Delta t=8 h$ & $5.1 \pm 6.9$ & $9.5 \pm 4.7$ & $7.29 \pm 10.0$ \\
\hline \multicolumn{4}{|c|}{$\begin{array}{l}\text { Second exercise } \\
\text { test }\end{array}$} \\
\hline Preexercise & $31.7 \pm 2.9$ & $30.5 \pm 2.4$ & $30.4 \pm 7.3$ \\
\hline$\Delta t=1 h$ & $20.69 \pm 8.6$ & $11.7 \pm 4.1$ & $5.7 \pm 3.1 \dagger$ \\
\hline$\Delta \mathrm{t}=8 \mathrm{~h}$ & $13.3 \pm 6.3$ & $3.8 \pm 3.9$ & $-8.9 \pm 15.9$ \\
\hline \multicolumn{4}{|l|}{$\operatorname{FABP}(\mu \mathrm{g} / \mathrm{L})$} \\
\hline \multicolumn{4}{|c|}{ First exercise test } \\
\hline Preexercise & $2.46 \pm 0.57$ & $2.44 \pm 0.65$ & $2.16 \pm 0.71$ \\
\hline$\Delta t=1 \mathrm{~h}$ & $0.78 \pm 0.61$ & $1.20 \pm 0.93$ & $0.81 \pm 0.81$ \\
\hline$\Delta \mathrm{t}=8 \mathrm{~h}$ & $0.73 \pm 0.82$ & $0.92 \pm 0.86$ & $0.27 \pm 0.68$ \\
\hline \multicolumn{4}{|c|}{$\begin{array}{l}\text { Second exercise } \\
\text { test }\end{array}$} \\
\hline Preexercise & $2.73 \pm 1.02$ & $2.96 \pm 0.52$ & $2.29 \pm 0.90$ \\
\hline$\Delta t=1 h$ & $1.55 \pm 1.16$ & $0.21 \pm 0.55^{*}$ & $1.02 \pm 1.43$ \\
\hline$\Delta \mathrm{t}=8 \mathrm{~h}$ & $0.53 \pm 0.52$ & $-0.01 \pm 0.65 \dagger$ & $0.15 \pm 1.32 \ddagger$ \\
\hline
\end{tabular}

NOTE. First exercise test, before any treatment; second exercise test, after 6 weeks of treatment. For $\Delta t=1 \mathrm{~h}$, data on plasma CK levels are calculated as follows: $1 \mathrm{~h}$ postexercise minus preexercise $C K$ level.

$* P=.028,+P=.043, \neq P=.046: v$ first exercise test. 

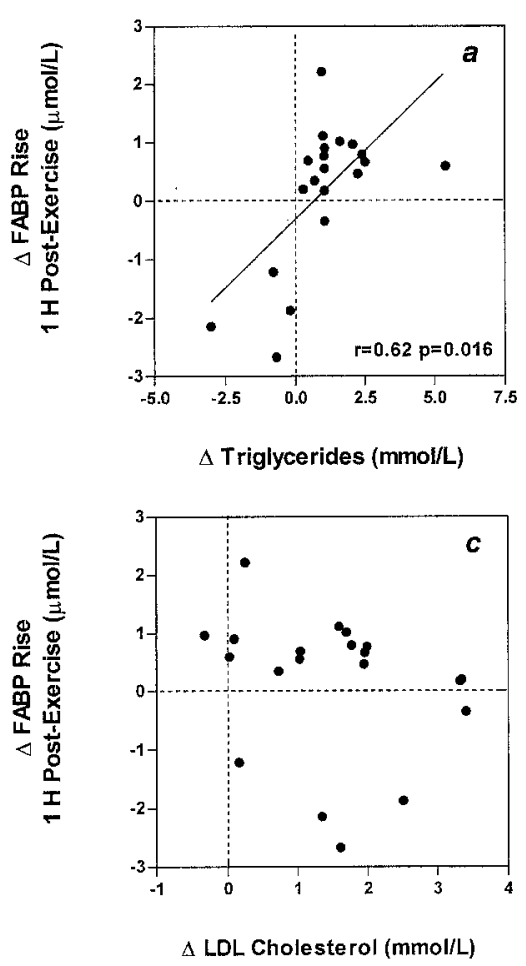

els remains to be elucidated. In addition, the question remains as to why changes in LDL cholesterol levels with fluvastatin appeared not to contribute to the improved postexercise muscle protein release. In this study, we found evidence for skeletal muscle pathology in untreated hypertriglyceridemia. As a consequence, the elevated muscle protein levels observed directly after starting therapy for combined hyperlipidemia may result from the disease rather than the therapy. However, we still advise monitoring patients on combination therapy for adverse effects. It appears from the literature that myopathy during therapy with HMG-CoA reductase inhibitors is associated with elevated systemic levels of these agents, which can occur in the case of hepatic or, multiple-organ failure or during concomitant therapy with agents that interfere with the hepatic clearance of HMG-CoA reductase inhibitors (eg, cyclosporin). ${ }^{38}$ The mechanism of muscle toxicity by statins may be a direct toxic effect ${ }^{39}$

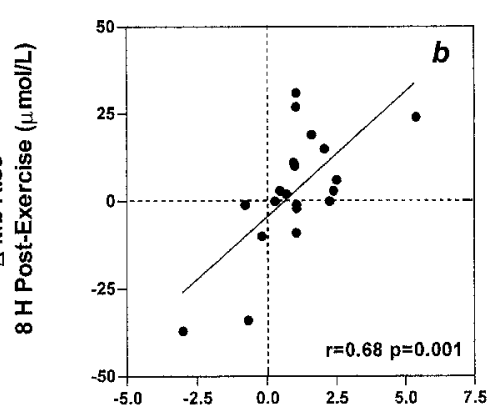

$\Delta$ Triglycerides $(\mathrm{mmol} / \mathrm{L})$

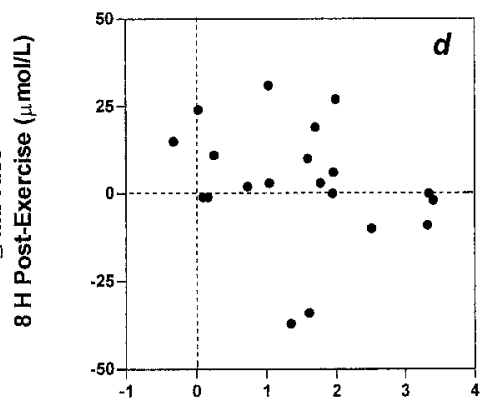

$\triangle$ LDL Cholesterol (mmol/L)
Fig 2. Correlations between changes $(\triangle)$ in plasma triglycerides or LDL cholesterol and changes in exercise-induced increments of plasma muscle proteins (FABP 1 hour postexercise and $\mathrm{Mb} 8$ hours postexercise) in 20 subjects with combined hy perlipidemia. The data reflect changes $v$ baseline (before therapy) after 6 weeks of treatment with fluvastatin $40 \mathrm{mg} / \mathrm{d}$, gemfibrozil $600 \mathrm{mg}$ twice daily, or a combination of both. $\triangle$, baseline value minus value after therapy.

or perhaps represents a yet unknown interaction with a genetic muscle susceptibility. Gemfibrozil may induce myopathy, especially when renal function is impaired.

In conclusion, in this study, evidence has been found that combined hyperlipidemia is associated with increased release of muscle proteins after exercise and that decreasing triglyceridecarrying lipoproteins ameliorates the exercise endurance of skeletal muscle. The clinical significance of these observations remains to be proven. The decision on which therapy to use in the prevention of coronary heart disease should be based primarily on efficacy with regard to clinical relevant endpoints.

\section{ACKNOWLEDGMENT}

The authors gratefully acknowledge M. Pelsers for expert technical assistance.

\section{REFERENCES}

1. Law MR, Wald NJ, Thompson SG: By how much and how quickly does reduction in serum cholesterol concentration lower risk of ischaemic heart disease? BMJ 308:367-373, 1994

2. Manninen V, Tenkanen L, Koskinen P, et al: Joint effects of serum triglyceride and LDL and HDL cholesterol concentrations on coronary heart disease risk in the Helsinki Heart Study. Implications for treatment. Circulation 85:37-45, 1992

3. Criqui MH, Heiss G, Cohn R, et al: Plasma triglyceride level and mortality from coronary heart disease. N Engl J Med 328:1220-1225, 1993

4. Ericsson C, Hamsten A, Nilsson J, et al: Angiographic assessment of effects of bezafibrate on progression of coronary artery disease in young male post-infarction patients. Lancet 347:849-853, 1996

5. Vega GL, Grundy SM: Management of primary mixed hyperlipidaemia with lovastatin. Arch Intern Med 150:1313-1319, 1990
6. Kesaniemi YA, Grundy SM: Influence of gemfibrozil and clofibrate on metabolism of cholesterol and plasma triglycerides in man. JAMA 251:2241-2246, 1984

7. Illingworth DR, Bacon S: Influence of lovastatin plus gemfibrozil on plasma lipids and lipoproteins in patients with familial combined hyperlipidaemia. Circulation 79:590-596, 1989

8. Feussner G, Eichinger M, Ziegler R: The influence of simvastatin alone or in combination with gemfibrozil on plasma lipids and lipoproteins in patients with type III hyperlipoproteinaemia. Clin Invest 70:1027-1035, 1992

9. Athyros VG, Papageorgiou AA, Hatzikonstandinou HA, et al: Safety and efficacy of long term statin-fibrate combinations in patients with refractory familial combined hyperlipidemia. Am J Cardiol 80:608-613, 1997

10. Bradford RH, Shear CL, Chremos AN, et al: Expanded Clinical 
Evaluation of Lovastatin (EXCEL) Study results. I. Efficacy in modifying plasma lipoproteins and adverse event profile in 8245 patients with moderate hypercholesterolaemia. Arch Intern Med 151:43-49, 1991

11. Kogan AD, Orenstein S: Lovastatin induced acute rhabdomyolysis. Postgrad Med J 66:294-296, 1990

12. Deslypere JP, Vermeulen A: Rhabdomyolysis and simvastatin. Ann Intern Med 114:342, 1991 (letter)

13. Chucrullah A, De Girolami U, Freeman R, et al: Lovastatin/ gemfibrozil myopathy: A clinical, histochemical and ultrastructural study. Eur Neurol 32:293-296, 1992

14. Pierce LR, Wysowski DK, Gross TP: Myopathy and rhabdomyolysis associated with lovastatin-gemfibrozil combination therapy. JAMA 264:71-75, 1990

15. Tal A, Rajeshawari M, Isley W: Rhabdomyolysis associated with simvastatin-gemfibrozil therapy. South Med J 90:546-547, 1997

16. Blane GF: Comparative toxicity and safety profile of fenofibrate and other fibric acid derivatives. Am J Med 83:26-36, 1987 (suppl 5B)

17. Bhatnagar D, Durrington PN, Neary R, et al: Elevation of skeletal muscle isoform of serum creatine kinase in heterozygous familial hypercholesterolaemia. J Intern Med 228:493-495, 1990

18. Smit JWA, Bär PR, Erkelens DW: Hypercholesterolaemia is associated with increased exercise induced leakage of muscle proteins, which is not aggravated by simvastatin therapy. Eur J Clin Invest 25:79-84, 1995

19. Egashira $\mathrm{K}$, Inou T, Hirooka $\mathrm{Y}$, et al: Impaired coronary blood flow in response to acetylcholine in patients with coronary risk factors and proximal atherosclerotic lesions. J Clin Invest 91:29-37, 1993

20. Treasure CB, Klein JL, Weintraub WS, et al: Beneficial effects of cholesterol lowering therapy on the coronary epithelium in patients with coronary artery disease. N Engl J Med 332:481-487, 1995

21. Anderson TJ, Meredith IT, Yeung AC, et al: The effect of cholesterol lowering and antioxidant therapy on endothelium dependent coronary vasomotion. N Engl J Med 332:488-493, 1995

22. Chowienezyk PJ, Watts GF, Crockroft JR, et al: Impaired endothelium dependent vasodilatation of forearm resistance vessels in hypercholesterolaemia. Lancet 340:1430-1432, 1992

23. Stroes ESG, Koomans HA, De Bruin TWA, et al: Vascular function in the forearm of hypercholesterolaemic patients off and on lipid lowering medication. Lancet 346:467-471, 1995

24. Hayoz D, Weber R, Rutschmann B, et al: Postischaemic blood flow response in hypercholesterolaemic patients. Hypertension 26:497502,1995

25. Tur E, Politi Y, Rubinstein A: Cutaneous blood flow abnormalities in hypertriglyceridaemia. J Invest Dermatol 103:597-600, 1994

26. Lundman P, Eriksson M, Schenck-Gustafsson K, et al: Transient triglyceridaemia decreases vascular reactivity in young healthy men without risk factors for coronary heart disease. Circulation 96:32663268,1997

27. Lewis TV, Dart AM, Chin-Dusting JP: Endothelium-dependent relaxation by acetylcholine is impaired in hypertriglyceridemic humans with normal levels of plasma LDL cholesterol. J Am Coll Cardiol 33:805-812, 1999

28. Hermann FH, Spiegler A, Wiedman G: Muscle provocation test. A sensitive method of discrimination between carriers and non-carriers of Duchennen muscular dystrophy. Hum Genet 61:102-104, 1982

29. Driessen-Kletter MF, Amelink GJ, Bär PR, et al: Myoglobin is a sensitive marker of increased muscle membrane vulnerability. J Neurol 237:234-238, 1990

30. Van Nieuwenhoven FA, Kleine AH, Wodzig WH, et al: Discrimination between myocardial infarction and skeletal muscle injury by assessment of the plasma ratio of myoglobin over fatty acid binding protein. Circulation 92:2848-2854, 1995

31. Glatz JF, Van der Vusse GJ, Simoons ML, et al: Fatty acidbinding protein and the early detection of myocardial infarction. Clin Chim Acta 9:87-92, 1998

32. Sorichter S, Mair J, Koller A, et al: Early assessment of exercise induced skeletal muscle injury using plasma fatty acid binding protein. Br J Sports Med 306:121-124, 1998

33. Friedewald WT, Levy RJ: Estimation of the composition of low-density lipoprotein cholesterol in plasma, without use of the preparative ultracentrifuge. Clin Chem 18:499-592, 1972

34. Keller H, Mahfoudi A, Dreyer C, et al: Peroxisome proliferator activated receptors and lipid metabolism. Ann NY Acad Sci 684:157173,1993

35. London SF, Gross KF, Ringel SP: Cholesterol-lowering agent myopathy (CLAM). Neurology 41:1159-1160, 1991

36. Jeng CY, Sheu WH, Fuh MM, et al: Gemfibrozil treatment of endogenous hypertriglyceridaemia: Effect on insulin-mediated glucose disposal and plasma insulin concentrations. J Clin Endocrinol Metab $81: 2550-2553,1996$

37. Veerkamp JH, van Moerkerk HT: Fatty acid-binding protein and its relation to fatty acid oxidation. Mol Cell Biochem 300:101-106, 1993

38. Smith PF, Eydelloth RS, Grossman SJ, et al: HMG-CoA reductase inhibitor induced myopathy in the rat: Cyclosporine A interaction and mechanism studies. J Pharmacol Exp Ther 257:12251235,1991

39. Veerkamp JH, Smit JWA, Benders AAGM, et al: Effects of HMG-CoA reductase inhibitors on growth and differentiation of cultured rat skeletal muscle cells. Biochim Biophys Acta 1315:217-222, 1996 